\author{
家庭用品に含有されるトリブチルスズ，トリフェニルスズの分析法 \\ 一公定分析法の改定にむけて一 \\ 中島晴信, ${ }^{*}, a$ 富山健一, ${ }^{b}$ 河上強志, ${ }^{c}$ 伊佐間和郎 $c$
}

\title{
Analytical Method for Tributyltin and Triphenyltin Contained in Household Products - Preparing for the Revision of Authorized Analytical Method-
}

\author{
Harunobu NaKashima, ${ }^{*, a}$ Ken-ichi TOMiYAma, ${ }^{b}$ Tsuyoshi KaWAKAmi, ${ }^{c}$ and Kazuo IsAma ${ }^{c}$ \\ a Osaka Prefectural Institute of Public Health, 1-3-69 Nakamichi, Higashinari-ku, Osaka 537-0025, \\ Japan, ${ }^{b}$ University of Shizuoka, 52-1 Yada, Suruga-ku, Shizuoka 422-8526, Japan, and ${ }^{c}$ National \\ Institute of Health Sciences, 1-18-1 Kamiyoga, Setagaya-ku, Tokyo 158-8501, Japan
}

(Received January 19, 2010; Accepted April 20, 2010; Published online April 20, 2010)

\begin{abstract}
In preparing for the revision of the authorized analytical method for tributyltin (TBT) and triphenyltin (TPT), which are banned from using according to the "Act on the Control of Household Products Containing Harmful Substances", an examination was conducted on the detection method of these substances using gas chromatography/mass spectrometry (GC/MS), after derivatizing them (ethyl-derivatizing method and hydrogen-derivatizing method). Ethylderivatized compounds had stability, which enabled the detection of TPT with a higher sensitivity. In addition, a preparation suitable for the following analytical objects was established: (1) textile products, (2) water-based products (such as water-based paint), (3) oil-based products (such as wax), and (4) adhesives. Addition-recovery experiments were conducted using the prescribed pretreatment method, when each surrogate substances (TBT-d27, TPT-d15) were added and the data were corrected, good recovery rates $(94.5-118.6 \%$ in TBT, and $86.6-110.1 \%$ in TPT) were obtained. When TBT and TPT in 31 commercially available products were analyzed based on the developed analytical method, an adhesive showed $13.2 \mu \mathrm{g} / \mathrm{g}$ of TBT content, which exceeded the regulatory criterion $(1 \mu \mathrm{g} / \mathrm{g}$ as tin). Next, when the same products with different manufacturing date were analyzed, TBT $(10.2-10.8 \mu \mathrm{g} / \mathrm{g})$, which exceeded the regulatory criterion, was detected in 4 products among 8 products, and simultaneously, a high concentration (over $1000 \mu \mathrm{g} / \mathrm{g}$ ) of dibutyltin (DBT) was detected. It was suggested that TBT as an impurity of DBT remained, and the manufacturer chose the voluntary recall of the product. The new method is considered sufficiently applicable as a revised method for the conventionally authorized method.
\end{abstract}

Key words_ — tributyltin; triphenyltin; GC/MS; household product; ethyl-derivation; hydrogen-derivation

\section{緒}

有機スズ化合物は，ポリ塩化ビニルの安定剂，高 分子化合物の重合触媒，防菌・防かび剂，船底塗 料，漁網の防污剂などとして広範な分野で使用され てきた. 1)これら化合物は，免疫毒性，神経毒性を 有することがよく知られている. ${ }^{2-5)}$ そこで, 1978 年に「有害物質を含有する家庭用品の規制に関する 法律」により，家庭用品にはトリブチルスズ化合物 （TBT）及びトリフェニルスズ化合物（TPT）を使 用することが禁止され，公定法も定められた。 ${ }^{6)}$ 公

$a$ 大阪府立公衆衛生研究所, $b$ 静岡県立大学, $c$ 国立医薬 品食品衛生研究所

*e-mail: hrnakaji@iph.pref.osaka.jp
定法は，フレームレス原子吸光法（AAS）でスズ 量を測定し， $1 \mu \mathrm{g} / \mathrm{g}$ 以上のスズが検出された場合， 2 次元薄層クロマトグラフ法 (TLC) で展開した後, ジチゾンで発色させて確認する方法である. ${ }^{7,8)} し か$ し, 公定法に従つて分析すると, スズが検出される が，ジチゾン錯体が発色後速やかに消失するなど， スズの種類が判定できない場合が多い，特に，使用 禁止ではないジブチルスズ化合物（DBT）やジオ クチル化合物（DOT）が大量に共存する場合には, その判定は一層困難となる. ${ }^{9-11)}$ 筆者らは, ポスト カラム蛍光誘導体化を用いた HPLCによるジアル キルスズ化合物の分離分析法, ${ }^{12)}$ さらにプレカラム を利用したカラムスイッチング法による DBT 及び DOT の定量法13)を既に報告している。 また，家庭 
用品, ${ }^{10,11,14-20)}$ 食品用容器包装, ${ }^{21-25)}$ 水 - 土壤 - 魚 中の環境試料中 ${ }^{26-29)}$ の有機スズの分析法として, 安 定な誘導体化物（プロピル化, 水素化, エチル化な ど）にし, GC 法 (ECD, FPD, AED, MS) で検出 する多くの報告がある.

現公定法は改定の必要がある。そのため，河上ら は，GC/MS による水性製品中の有機スズ化合物の 分析法を報告している. ${ }^{30)}$ 本研究では，法律で規定 されている家庭用品全般について，分析法を検討し た。まず， TBT 及び TPT を誘導体化（エチル化， 水素化）し， GC/MS で検出する方法を検討した. 家庭用品は，多種多様な物質から構成され，しか も，構成成分が全く異なる製品も多く，対象製品に より各々の前処理法を作成する必要がある，特に， 油性製品（油性塗料，靴墨，ワックスなど）やゴム 系接着剂中の TBT, TPT の分析は困難で, 分析法 の報告はほとんぞ見当たらない。そこで，1）繊維 製品，2）水性製品(水性塗料など)，3）油性製品,

4）接着剤（アセトン可溶性，水・油ともに難溶性） と，各々異なる前処理法を確立した。さらに，開発 した分析法で，市販製品中の有機スズ化合物を分析 したので報告する.

\section{実 験 方 法}

1. 試料市販の繊維製品（8 製品，9 部位), 水性塗料（4 製品），接着剂（20 製品）及び油性製 品（塗料，靴墨など 7 製品）の計 40 試料を試験試 料とした。

2. 試薬 標準試薬：塩化トリブチルスズ （TBT）及び塩化トリフェニルスズ（TPT）は，東 京化成工業社製の標準試薬を用いた。 TBT と TPT のサロゲート物質である $\mathrm{TBT}-\mathrm{d}_{27}$ 及び $\mathrm{TPT}-\mathrm{d}_{15}$ は，林純薬工業社製を用いた。塩化ジブチルスズ （DBT）は東京化成工業社製, 塩化ジフェニルスズ （DPT）はアルファプロダクト社製, 塩化ジオクチ ルスズ（DOT）は東京ファインケミカル社製の標 準試薬を用いた。標準溶液系列は $1000 \mu \mathrm{g} / \mathrm{ml}$ のへ キサン標準原液を作製し，ヘキサンで用時希釈調製 した.

テトラエチルホウ酸ナトリウム $\left(\mathrm{NaBEt}_{4}\right)$ は林 純薬工業社製の水質試験用（純度 $98 \%$ 以上）試薬 を, 水素化ホウ素ナトリウム $\left(\mathrm{NaBH}_{4}\right)$ は関東化 学工業社製の原子吸光分析用を用いた。シリカゲル
カートリッジカラム及びフロリジルカートリッジカ ラムは，Waters 社製セップパックプラスを用いた.

リン酸ークエン酸緩衝液（pH 2) は，公定法6)に 準じて調製した。酢酸一酢酸ナトリウム緩衝液（pH 5.0) は, $2 \mathrm{~mol} / 1$ 酢酸と $2 \mathrm{~mol} / 1$ 酰酸ナトリウム水 溶液を $5.9: 14.1$ の割合で混合後, pH 5.0 に調整し た.

ヘキサン，メタノール，アセトン，エタノールは 和光純薬工業侏製の残留農薬試験用を用いた.

3. GC/MS 装置及び条件 GC/MS は, Hewlett Packard 製 5890 Series II GC に MSD 検出器（HP MSD5971）を装着した装置を用い，自動注入装置 は, Hewlett Packard 製 7673 型を用いた。 キャピ ラリーカラムは, DB-5 ms $(0.25 \mathrm{~mm} \phi \times 25 \mathrm{~m}$, 膜 厚 $0.25 \mu \mathrm{m}, \mathrm{J} \& \mathrm{~W}$ 社製）を用いた. エチル誘導体 及び水素化誘導体の測定は，同じ測定条件にした. キャリアーガス流量は, He $2 \mathrm{ml} / \mathrm{min}$ に設定した。 カラム温度 (エチル誘導体及び水素化誘導体の測定) は, $50^{\circ} \mathrm{C}(1 \mathrm{~min})-10^{\circ} \mathrm{C} / \mathrm{min}-220^{\circ} \mathrm{C}-5^{\circ} \mathrm{C} / \mathrm{min}-260^{\circ} \mathrm{C}-$ $20^{\circ} \mathrm{C} / \mathrm{min}-280^{\circ} \mathrm{C}(5 \mathrm{~min})$ にプログラミングし, 注 入口温度は $270^{\circ} \mathrm{C}$, インターフェイス温度は $280^{\circ} \mathrm{C}$ に設定した。注入方法はスプリットレス法で，注入 量は $2 \mu \mathrm{l}$ にした。イオン化法は EI（Electron Ionization）法で，イオン化電圧は $70 \mathrm{eV}$ とした。測定 は SIM (Selected Ion Monitoring) モードで行っ た。エチル誘導体の SIM イオン值 $(m / z)$ を, 定 量イオン，確認イオンの順に示す。；DBT（263, $261)$, TBT $^{-\mathrm{d}_{27}}(318,316)$, TBT $(263,261)$, DPT $(303,301)$, DOT $(375,373)$, TPT-d $\mathrm{d}_{15}(366,364)$, TPT $(351 ， 349)$ 。また, 水素化誘導体の各 SIM 个 オン值 $(\mathrm{m} / \mathrm{z})$ を, 定量イオン, 確認イオンの順に 示す。 ; DBT $(179,177)$, TBT- $\mathrm{d}_{27}(253,251)$, TBT (179, 177), DPT $(197,195)$, DOT $(235,233)$, TPT-d ${ }_{15}(284,282)$, TPT $(274,272)$.

なお，有機スズ化合物は誘導体を測定したが，標 準品はすべて塩化物を用いている. したがって，有 機スズ分析値は，塩化物として表記している.

\section{4. 試験溶液の調製}

4-1. 繊維製品 細切した試料 $1 \mathrm{~g}$ を，ナス型 フラスコに秤量し，塩酸一メタノール溶液 $75 \mathrm{ml}$ を 加え, 内部標準物質として各サロゲート物質 $\left(\mathrm{TBT}-\mathrm{d}_{27}, \mathrm{TPT}-\mathrm{d}_{15}\right)$ を添加した後, 30 分間 $70^{\circ} \mathrm{C}$ で 還流抽出した。抽出液をガラスろ過器でろ過し, 
$300 \mathrm{ml}$ の分液ロートにとつた. $25 \mathrm{ml}$ のメタノール でガラス器具を洗浄して, 洗液とろ液をあわせた. リン酸ークエン酸緩衝液（pH 2）50 ml 及び精製水 $100 \mathrm{ml}$ ，ヘキサン $30 \mathrm{ml}$ を加え振とうした後，へキ サン相を分取した。 さらに，ヘキサン $30 \mathrm{ml}$ を加え て振とう後，ヘキサン相をあわせた。抽出液を硫酸 ナトリウムで脱水し，ガラスろ過器でろ過した。 ろ 液をロータリーエバポレーターで $10 \mathrm{ml}$ に濃縮し, あらかじめへキサンで調製したシリカゲルカートリ ッジカラムに負荷した。 カラムをへキサン $30 \mathrm{ml}$ で 洗浄した後, $20 \%$ エタノール含有ヘキサン $20 \mathrm{ml}$ で 有機スズを溶出させた。溶出液をナス型フラスコに とり，ロータリーエバポレーターで数 $\mathrm{ml}$ まで減圧 濃縮 $\left(40^{\circ} \mathrm{C}\right.$ 以下）し，アルゴン気流下で溶媒を留 去した.この後エチル化法と水素化法の 2 法で誘導 体化した.

（1）エチル化法 ; フラスコにヘキサン $2 \mathrm{ml}$ を加 えて残渣を再溶解した。 その溶液を $50 \mathrm{ml}$ 遠沈管に とり, $5 \% \mathrm{NaBEt}_{4}$ エ夕ノール溶液 $1 \mathrm{ml}$, 酢酸-酢酸 ナトリウム緩衝液（pH 5.0） $5 \mathrm{ml}$ を加え，激しく 振とうし，室温で 30 分間反応させた。 さらに，へ キサン $8 \mathrm{ml}$ を加え，エチル化した有機スズを抽出 した。抽出液をロータリーエバポレーターで $2 \mathrm{ml}$ に濃縮した後，濃縮液をフロリジルカラムに負荷し， $5 \%$ ジエチルエーテルーヘキサン $8 \mathrm{ml}$ で溶出した. 溶出液を，無水硫酸ナトリウムで脱水した後，定容 して GC/MS 測定試料とした.

（2）水素化法26)；フラスコ中の残渣をへキサン $5 \mathrm{ml}$ で再溶解した，溶液を $20 \mathrm{ml}$ 試験管にとり，5 $\% \mathrm{NaBH}_{4}$ エ夕ノール溶液 $2 \mathrm{ml}$ を加え，静かに振と うして, 室温で 15 分間反応させた. 反応後, 精製 水 $10 \mathrm{ml}$ を加えへキサン相 $5 \mathrm{ml}$ を試験管に移し, 無水硫酸ナトリウムを加えて脱水した後, 定容して $\mathrm{GC} / \mathrm{MS}$ 測定試料とした。

4-2. 水性塗料 あらかじめ精製水 $20 \mathrm{ml}$ を入 れた $50 \mathrm{ml}$ の密栓付遠沈管に, 試料 $0.5 \mathrm{~g}$ を秤量し た。へキサン $20 \mathrm{ml}$ 及び濃塩酸 4 滴 $(400 \mu \mathrm{l})$ を加 え，各サロゲート物質を添加した．密栓した遠沈管 を 30 分間振とうし， $3000 \mathrm{rpm}$ で 5 分間遠心分離し た。へキサン相（上相） $10 \mathrm{ml}$ を分取して，硫酸ナ トリウムで脱水し，ガラスろ過器でろ過した。その 溶液をロータリーエバポレーターで数 $\mathrm{ml}$ まで減圧 濃縮し，あらかじめへキサンで調製したシリカゲル
カートリッジカラムに負荷した. カラムをへキサン $30 \mathrm{ml}$ で洗浄した後，20\%エタノール含有へキサン $20 \mathrm{ml}$ で有機スズを溶出させた．溶出液をナス型フ ラスコにとり，ロータリーエバポレーターで数 $\mathrm{ml}$ まで減圧濃縮（ $40^{\circ} \mathrm{C}$ 以下）し，アルゴン気流下で 溶媒を留去した。その後, 上述の誘導体化（エチル 化又は水素化）を行い $\mathrm{GC} / \mathrm{MS}$ 測定した.

4-3. 油性塗料やワックスなどの油性製品 あ らかじめへキサン $20 \mathrm{ml}$ を入れた $50 \mathrm{ml}$ の密栓付遠 沈管に，試料 $0.5 \mathrm{~g}$ を秤量した。精製水 $20 \mathrm{ml}$ 及び 濃塩酸 4 滴 $(400 \mu \mathrm{l})$ を加え，各サロゲート物質を 添加した。密栓した遠沈管を 30 分間振とうし, $3000 \mathrm{rpm}$ で 5 分間遠心分離した。へキサン相（上 相） $10 \mathrm{ml}$ を分取して, 硫酸ナトリウムで脱水後, ガラスろ過器でろ過した，その溶液をロータリーエ バポレーターで数 $\mathrm{ml}$ まで減圧濃縮し，あらかじめ ヘキサンで調製したシリカゲルカートリッジカラム に負荷した. カラムをへキサン $30 \mathrm{ml}$ で洗浄した後, $20 \%$ エタノール含有ヘキサン $20 \mathrm{ml}$ で有機スズを溶 出させた。溶出液をナス型フラスコにとり，ロータ リーエバポレーターで数 $\mathrm{ml}$ まで減圧濃縮 $\left(40^{\circ} \mathrm{C}\right.$ 以 下）し，アルゴン気流下で溶媒を留去した。その 後，誘導体化を行い GC/MS 測定した。

\section{4-4. 接着剂}

4-4-1. 水溶性の接着剤水に可溶な製品は, 水性塗料と同様の調製法を行った.

4-4-2. アセトン可溶の接着剤水に難溶だ が，アセトンには可溶な製品は，以下の調製法を行 った。あらかじめアセトン $10 \mathrm{ml}$ の入った $50 \mathrm{ml}$ の 密栓付遠沈管に, 試料 $1.0 \mathrm{~g}$ を秤量した。試料の溶 解を確認した後, ヘキサン $15 \mathrm{ml}$ と精製水 $15 \mathrm{ml}$ 及 び濃塩酸 4 滴 $(400 \mu \mathrm{l})$ を加え，各サロゲート物質 を添加した。密栓した遠沈管を 30 分間振とうし, $3000 \mathrm{rpm}$ で 5 分間遠心分離した。ヘキサン相をナ ス型フラスコに分取した。 さらにヘキサン $20 \mathrm{ml}$ を 入れ，同様の操作を行い，へキサン相をあわせた. その溶液を硫酸ナトリウムで脱水後, ガラスろ過器 でろ過した．万液をロータリーエバポレーターで数 $\mathrm{ml}$ まで減圧濃縮し，あらかじめへキサンで調製し たシリカゲルカートリッジカラムに負荷した. カラ ムをへキサン $30 \mathrm{ml}$ で洗浄した後，20\%エタノール 含有へキサン $20 \mathrm{ml}$ で有機スズを溶出させた．溶出 液をナス型フラスコにとり，ロータリーエバポレー 


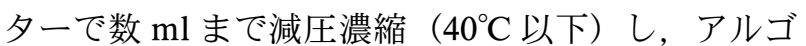
ン気流下で溶媒を留去した。 その後, 誘導体化を行 い GC/MS 測定した.

4-4-3. ゴムなどを主成分とする有機溶剤系接着 剤水, アセトン, ヘキサンいずれも不溶な接着 剤は，あらかじめジクロロメタン $10 \mathrm{ml}$ の入った $50 \mathrm{ml}$ の密栓付遠沈管に, 試料 $0.50 \mathrm{~g}$ を秤量した. 試料の溶解を確認した後, 各サロゲート物質を添加 し，ヘキサン $30 \mathrm{ml}$ ，濃塩酸 4 滴 $(400 \mu \mathrm{l})$ を加え た。遠沈管を 30 分間振とうし, $3000 \mathrm{rpm}$ で 5 分間 遠心分離した。抽出液（ヘキサンージクロロメタン 相）をナス型フラスコにとった。 その溶液をロータ リーエバポレーターで数 $\mathrm{ml}$ まで減圧濃縮し, あら かじめへキサンで調製したシリカゲルカートリッジ カラムに負荷した. カラムをへキサン $30 \mathrm{ml}$ で洗浄 した後， $20 \%$ エタノール含有ヘキサン $20 \mathrm{ml}$ で有機 スズを溶出させた。溶出液をナス型フラスコにと り，ロータリーエバポレーターで数 $\mathrm{ml}$ まで減圧濃 縮 $\left(40^{\circ} \mathrm{C}\right.$ 以下）し，アルゴン気流下で溶媒を留去 した。 その後, 誘導体化を行い $\mathrm{GC} / \mathrm{MS}$ 測定した.

\section{結果及び考察}

\section{1. 有機スズ化合物の GC/MS 分析 分析対象} 有機スズ化合物として, TBT, TPT 及び内部標準物 質の TBT- $\mathrm{d}_{27}, \mathrm{TPT}-\mathrm{d}_{15}$ のほかに, 製品から検出す る可能性のある塩化ジブチルスズ (DBT), 塩化ジ フェニルスズ (DPT), 塩化ジオクチルスズ (DOT) の 7 種の有機スズ化合物の GC/MS 測定法を検討 した。

誘導体化法としては，3 種の誘導体化法（プロピ ル化，水素化，エチル化）が報告されている。プロ ピル化法は，GC/MS 測定には適さないため, $\mathrm{FPD}^{10,17)}$ や $\mathrm{AED}^{22)}$ 検出法が報告されている. エチ ル誘導体化試薬 $\mathrm{NaBEt}_{4}$ は高価であり, 試薬瓶（ア ンプル）開封後は，分解（黄変）し易く長期保存に 適さない。しかし，エチル誘導体は比較的安定であ る。一方, 水素化誘導体化試薬 $\mathrm{NaBH}_{4}$ は安価で, 試薬瓶開封後も薬品の長期保存が可能である上に, 水素化反応は簡便であるため，スクリーニング法と しては優れている。 そこで，エチル化法と水素化 法26)を比較検討した。

7 種のエチル誘導体 $(5 \mu \mathrm{g} / \mathrm{ml})$ と水素化誘導体 $(10 \mu \mathrm{g} / \mathrm{ml})$ の TIC（定量イオン＋確認イオン）を
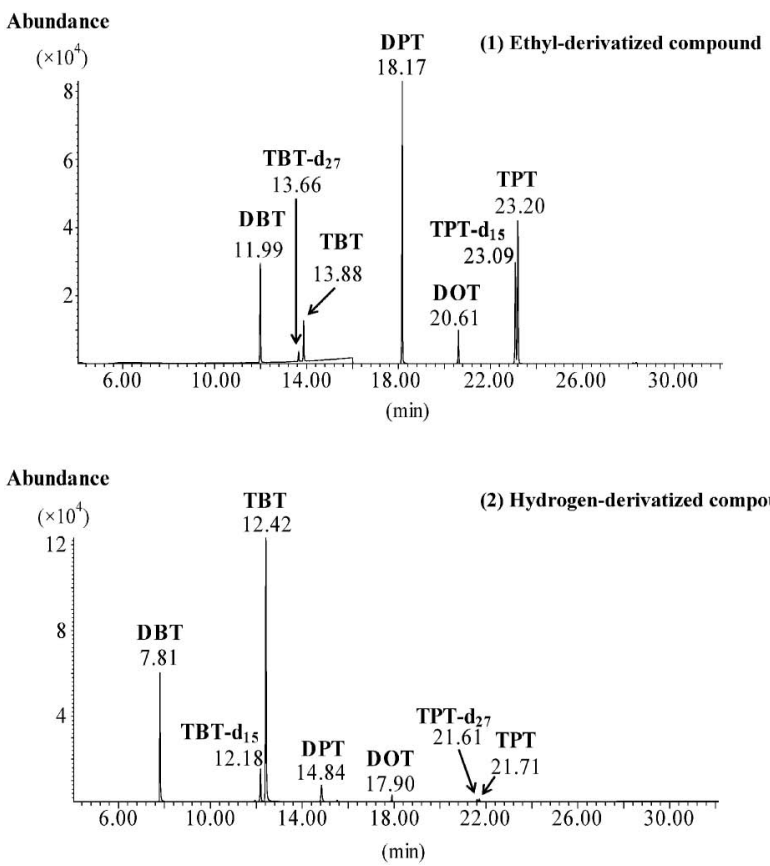

Fig. 1. Total Ion Chromatogram (SIM Mode) of Seven Types of Organotin Compounds

(1) Ethyl-derivatized compound $(5 \mu \mathrm{g} / \mathrm{ml})$ : For SIM, 12 ions were monitored $(\mathrm{m} / \mathrm{z}, 263$ and 261 for DBT and TBT, $\mathrm{m} / z 318$ and 316 for TBT- $\mathrm{d}_{27}, \mathrm{~m} / z 303$ and 301 for DPT, $\mathrm{m} / z 375$ and 373 for DOT, $\mathrm{m} / z 366$ and 364 for TPT- $\mathrm{d}_{15}$ and $m / z, 351$ and 349 for TPT; the underlined number is the $\mathrm{m} / \mathrm{z}$ of the ion used for quantification). (2) Hydrogen-derivatized compound $(10 \mu \mathrm{g} / \mathrm{ml})$ : For SIM, 12 ions were monitored $(\mathrm{m} / z 179$ and 177 for DBT and TBT, $m / z 253$ and 251 for TBT- $\mathrm{d}_{27}, m / z 197$ and 195 for DPT, $m /$ $z 235$ and 233 for DOT, $m / z 284$ and 282 for TPT- $\mathrm{d}_{15}$ and $m / z 274$ and 272 for TPT; the underlined number is the $\mathrm{m} / \mathrm{z}$ of the ion used for quantification).

Fig. 1 に示す．ピーク面積で比較すると，水素化誘 導体は，TBT- $\mathrm{d}_{27}$ と TBT ではエチル誘導体以上の 高感度（6 倍）が得られたが，TPT- $\mathrm{d}_{15}$ と TPT の 感度は，エチル誘導体と比べて低感度（1/45 倍） であった。 TBT の定量法としては，水素化法でも 十分な感度が得られるが，TPT 測定には，エチル 化法が優れている.

誘導体の安定性及び TPT の測定感度を考慮すれ ば，エチル化法を公定分析法として採用する方がよ いと考えられる，そこで，水素化法でスクリーニン グし，有機スズが検出した場合にエチル化法を行つ て定量することとした.

これら 7 種の有機スズ化合物のエチル誘導体化物 の検出限界は， $\mathrm{S} / \mathrm{N}=5$ として 2-10 pg であった． 1 $\mu \mathrm{g} / \mathrm{ml}$ の 5 回繰り返し注入の再現性も良好であった $(\mathrm{CV}=1 \%$ 以下). 各定量イオンによる検量線を作成 したところ，いずれも $0.01-2 \mu \mathrm{g} / \mathrm{ml}$ の範囲で $\mathrm{R}^{2}=$ 0.99 以上の良好な直線性を示した。それら検量線 
から，各有機スズ化合物の定量值（検出值）を算出 した（絶対検量線法）.

次に, エチル誘導体化試薬である高価な $\mathrm{NaBEt}_{4}$ 溶液の保存法の検討を行った。 $\mathrm{NaBEt}_{4}$ は水溶液に して反応させ，用時調製して使い切りにする報告が 多い. $18-20,24,25,27,28)$ そこで，5\% 水溶液及び $5 \%$ エ夕 ノール溶液中で，各有機スズを反応させ，GC/MS のピーク面積を比較したところ，ほぼ同じ結果が得 られた。また，冷暗所で 1 週間保存した $5 \%$ エ夕 ノール溶液でも，反応効率の変化はなかった。

分析目的である TBT と TPT は，各サロゲート 物質（TBT- $\mathrm{d}_{27}, \mathrm{TPT}-\mathrm{d}_{15}$ ）を内部標準物質として定 量した。 TBT の検出限界は， $\mathrm{S} / \mathrm{N}=5$ として $10 \mathrm{pg}$, TPT は $2 \mathrm{pg}$ であった。各サロゲート物質もほぼ同 じ感度が得られた。 TBT は $m / z 263$ （定量イオン） と, TBT $-\mathrm{d}_{27}$ の $m / z 318$ のイオン強度比の検量線に より定量した。 TPTは, $m / z 351$ (定量イオン) と, TPT- $\mathrm{d}_{15}$ の $m / z 366$ のイオン強度比の検量線から定 量した。検量線はいずれも $0.01-2 \mu \mathrm{g} / \mathrm{ml}$ の範囲で $\mathrm{R}^{2}=0.99$ 以上の良好な直線性を示した。

2. 液一液分配による極性物質の除去 TBT, TPT は水-ヘキサンによる液-液分配で $90 \%$ 以上 が，へキサン相に移行する。そこで，繊維製品の場 合には，繊維からの塩酸一メ夕ノール抽出液に水及 びへキサンを加えて TBT 及び TPT をへキサンに 再抽出することで，極性物質の除去をすることにし た。同様に，水性製品（水性塗料，接着剂）は水に 溶解した後，ヘキサンを加え，ヘキサン相に再抽出 することで，極性物質の除去をすることとした，油 性製品の場合にも，界面活性剤などの極性物質が共 存している。そこで，試料をへキサンに溶解した 後，水を加え，共存極性物質を水相に移行させて除 去することとした，接着剤のうちアセトンに溶解す るものは，溶解液に水とへキサンを加えて，TBT， TPT をへキサン相に再抽出して，共存極性物質を 除去することとした.

3. シリカゲルカラムによる無極性（脂溶性）物 質の除去＼cjkstart油性塗料やワックスなどの油性製品及 びゴムなどを主成分とする有機溶剂系接着剤は，大 量のパラフィン類やゴム成分を含有しており，水一 ヘキサンによる液-液分配後も，これら成分がとも にへキサン相に移行する。そこで，これら脂溶性物 質の除去法を検討した。まず，ヘキサンーヘキサン
飽和アセトニトリル分配で， TBT と TPT の分配率 を観察した。その結果，TBT は 20-30\%，TPT は 70-80\%が，アセトニトリル相に移行した. ${ }^{30)} \mathrm{TPT}$ の分析法としては有用であるが，TBT は 70-80\% がヘキサン相に残存する。 そこで，シリカゲルカラ ムによる脂溶性物質の除去法を検討した。 $10 \mu \mathrm{g} /$ $\mathrm{ml}, 100 \mu \mathrm{g} / \mathrm{ml}, 1000 \mu \mathrm{g} / \mathrm{ml}$ の TBT 及び TPT ヘキ サン溶液 $1 \mathrm{ml}$ をカラムに負荷し， $30 \mathrm{ml}$ のヘキサン で洗浄したところ，TBT 及び TPT はカラム中に残 存した。次に，20\%エタノール含有ヘキサン $20 \mathrm{ml}$ を流したところ， TBT の 100\%が， TPT の 80-100 \%が溶出した。そこで，へキサンで脂溶性物質を溶 出（除去）した後，20\%エタノール含有へキサン $20 \mathrm{ml}$ で TBT と TPT を溶出することにした。

4. ゴムなどを主成分とする有機溶剂系接着剤の 溶解とポリマーの除去ゴムなどを主成分とする 有機溶剤系接着剤には，水，アセトンなどの極性溶 媒，へキサンなどの非極性溶媒，いずれも不溶の製 品があった．まず，溶解可能な溶媒を検討し，ジク ロロメタンには溶解することが分かった。ジクロロ メタン溶解液より多い割合でへキサン（例えば 1： 3）を加えると，ヘキサン不溶の物質（ポリマー） が析出した。 そこで，ポリマーを析出させて除去し た後の溶解液（ジクロロメタン/ヘキサン混液）を 濃縮して，シリカゲルカラムによる脂溶性物質の除 去を行うことにした.

5. エチル誘導体化後の極性物質の除去 環境 試料中の有機スズ分析において，エチル化後に，フ ロリジルカラムによる精製法が報告されてい る. ${ }^{27,28)}$ そこで, エチル化した $10 \mu \mathrm{g} / \mathrm{ml}, 100 \mu \mathrm{g} /$ $\mathrm{ml}, 1000 \mu \mathrm{g} / \mathrm{ml}$ の TBT, TPT 各 $1 \mathrm{ml}$ をフロリジル カラムに負荷し，5％ジエチルエーテルーヘキサン $10 \mathrm{ml}$ で溶出したところ, 両物質とも $100 \%$ 溶出し た. そこで，この方法に従い，エチル誘導体化後の 極性物質の除去を行うこととした。なお，TBT は， $10 \mathrm{ml}$ ヘキサンでカラムから 100\%溶出した.

6. 市販製品の分析 前述したように，市販製 品の分析は，まず水素化法でスクリーニングし，有 機スズが検出した場合にエチル化法を行って定量し た. 各有機スズ化合物の定量值（検出値）は，エチ ル誘導体化物の各定量イオンによる検量線から算出 した。

家庭用品は，様々な物質から構成されているた 
め, 同一の抽出・精製操作を行っても，回収率は, 試料によって各々異なることが多い，例えば，界面 活性剤を含有した試料などは，液一液分配で液相が 幾相にもなり，へキサン相中の目的物質（TBT, TPT）が濃縮され，回収率が高くなることがある. 逆に, 塗料などでは, 固形物が析出し, 目的物質が トラップされて回収率が低くなることもある。 サロ ゲート物質は，標準品と同様の動きをする，定量目 的の TBT と TPT は，各サロゲート物質を内部標 準物質として補正して定量した(サロゲート補正)。

\section{6-1. 繊維製品市販乳幼児用繊維製品 8 製品} （9 部位）を分析した。 その結果を Table 1 に示す. No. 8 は高濃度の DBT No. 9 はDOTを検出し た事例製品であり，既に報告している. ${ }^{12-15)}$ 今回の 方法でも, やはり高濃度の DBT, DOT が検出され た. No. 1 から No. 7 までは今回購入した製品であ るが，No. 1 から微量の DBT と DOT が，No. 3, 4, 7 から微量の DOT が検出された。また, TBT, TPT 及び各サロゲート物質の 4 種の標準品 $1 \mu \mathrm{g}$ と

Table 1. Analytical Results of Textile Products

\begin{tabular}{|c|c|c|c|c|}
\hline $\begin{array}{l}\text { Sample } \\
\text { No. }\end{array}$ & Usage & $\begin{array}{l}\text { TBT } \\
(\mu \mathrm{g} / \mathrm{g})\end{array}$ & $\begin{array}{l}\text { TPT } \\
(\mu \mathrm{g} / \mathrm{g})\end{array}$ & $\begin{array}{l}\text { Other organotin } \\
\text { compounds }\end{array}$ \\
\hline 1 & Diaper cover & N.D. & N.D. & $\begin{array}{l}\text { DBT } 0.2 \mu \mathrm{g} / \mathrm{g} \text {, } \\
\text { DOT } 0.6 \mu \mathrm{g} / \mathrm{g}\end{array}$ \\
\hline 2 & Outer garment & N.D. & N.D. & \\
\hline 3 & Bib (surface cloth) & N.D. & N.D. & DOT $0.3 \mu \mathrm{g} / \mathrm{g}$ \\
\hline 4 & Bib (backing cloth) & N.D. & N.D. & DOT $0.6 \mu \mathrm{g} / \mathrm{g}$ \\
\hline 5 & Underwear & N.D. & N.D. & \\
\hline 6 & Diaper cover & N.D. & N.D. & \\
\hline 7 & Tank top & N.D. & N.D. & DOT $0.3 \mu \mathrm{g} / \mathrm{g}$ \\
\hline 8 & Diaper cover & 11.6 & N.D. & $\begin{array}{l}\text { DBT } 460 \mu \mathrm{g} / \mathrm{g}, \\
\text { DOT } 2.1 \mu \mathrm{g} / \mathrm{g}\end{array}$ \\
\hline 9 & Diaper cover & N.D. & N.D. & $\begin{array}{l}\text { DBT } 0.2 \mu \mathrm{g} / \mathrm{g}, \\
\text { DOT } 470 \mu \mathrm{g} / \mathrm{g}\end{array}$ \\
\hline
\end{tabular}

N.D.: not detected.
$10 \mu \mathrm{g}$ を，No. 1, 3, 4 に添加し回収実験を行ったと ころ，TBT は 83.5-125.2\%で， TPT は 48.1-108.3 \%であり，ばらつきがあった。しかし，各サロゲー 卜物質もほぼ同じ回収率が得られた。回収率が低い 製品（No. 3 への TPT $1 \mu \mathrm{g}$ 添加）もあったが，そ れでも $48.1 \%$ 以上なので，サロゲート補正しても よいと判断した。そこで，サロゲート補正を行う と，いずれも良好な回収率（TBT が 98-101.3\%， TPT が 95.2-101.7\%）が得られた。

6-2. 水性塗料 市販水性塗料 4 製品を分析し た。その結果を Table 2 に示す。これら製品からは いずれの有機スズも検出されなかった。また， TBT, TPT 及び各サロゲート物質の 4 種の標準品 $10 \mu \mathrm{g}$ と $100 \mu \mathrm{g}$ を, No. 1, 2, 4 に添加し回収実験を 行った。各々の回収率は，TBT が 48.4-63.6\%， TPT が 31.2-45.6\%であったが，サロゲート補正を 行うと, 繊維製品と同様に, 良好な回収率（TBT が 94.5-101.1\%, TPT が 104.4-110.1\%）が得られ た.

6-3. 油性塗料やワックスなどの油性製品 市 販の靴墨や，油性塗料など 7 製品を分析した。その 結果を Table 3 に示す。これら製品からも有機スズ は検出されなかった，TBT，TPT 及び各サロゲート 物質の 4 種の標準品 $10 \mu \mathrm{g}$ と $100 \mu \mathrm{g}$ を，すべての 製品に添加し回収実験を行った。回収率は, TBT が 100-156.3\%, TPT が 65.7-131.8\%であったが， サロゲート補正を行うと, やはり良好な回収率 （TBT が 95.2-118.6\%, TPT が 93.9-104.7\%）が得

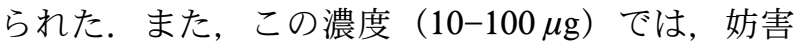
物質の影響もほとんごみられなかった. Figure 2 に No. 7 （油性木工用二ス）に 4 種の標準品各 $10 \mu \mathrm{g}$ 添加し, 操作法に従って処理した時の TIC を示 す。本法は，油性製品からの TBT 及び TPT の分 析法として十分適用可能と考えられる.

Table 2. Analytical Results of Water-based Paints

\begin{tabular}{|c|c|c|c|c|}
\hline $\begin{array}{l}\text { Sample } \\
\text { No. }\end{array}$ & Usage & $\begin{array}{l}\text { TBT } \\
(\mu \mathrm{g} / \mathrm{g})\end{array}$ & $\begin{array}{l}\text { TPT } \\
(\mu \mathrm{g} / \mathrm{g})\end{array}$ & Components \\
\hline 1 & Use for roofing & N.D. & N.D. & Synthetic resin (acryl), pigment, water \\
\hline 2 & Use for wall \& bathroom & N.D. & N.D. & Synthetic resin (acryl), pigment, water \\
\hline 3 & Use for iron part \& building & N.D. & N.D. & Synthetic resin (silicone-denatured), pigment, water \\
\hline 4 & Use for outdoor wood part & N.D. & N.D. & $\begin{array}{l}\text { Synthetic resin (akryl, alkyd), pigment, antiseptics, fungicide, } \\
\text { insecticide, water }\end{array}$ \\
\hline
\end{tabular}


Table 3. Analytical Results of Oil-based Paints

\begin{tabular}{|c|c|c|c|c|}
\hline $\begin{array}{l}\text { Sample } \\
\text { No. }\end{array}$ & Usage & $\begin{array}{l}\text { TBT } \\
(\mu \mathrm{g} / \mathrm{g})\end{array}$ & $\begin{array}{l}\mathrm{TPT} \\
(\mu \mathrm{g} / \mathrm{g})\end{array}$ & Components \\
\hline 1 & Shoe cream & N.D. & N.D. & Wax, grease, organic solvent \\
\hline 2 & Shoe cream & N.D. & N.D. & Wax, grease, organic solvent \\
\hline 3 & Polishing oil for furniture \& leather & N.D. & N.D. & Plant essence, paraffinic hydrocarbon \\
\hline 4 & Shoe cream & N.D. & N.D. & Wax, grease, organic solvent \\
\hline 5 & Wax for floor & N.D. & N.D. & Wax, grease, organic solvent \\
\hline 6 & Antiseptic mothproof paint & N.D. & N.D. & $\begin{array}{l}\text { Antiseptic insecticide for wood, pigment (without \# } 101 \text { color- } \\
\text { less pigment), organic solvent }\end{array}$ \\
\hline 7 & Coloring vanish for woodworking & N.D. & N.D. & Synthetic resin (urethane resin), pigment, organic solvent \\
\hline
\end{tabular}

N.D.: not detected.

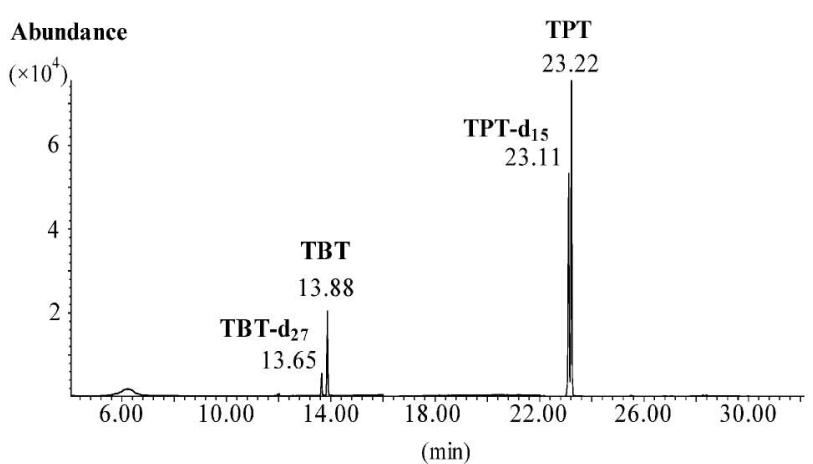

Fig. 2. Total Ion Chromatogram (SIM Mode) of a Recovery Experiment

Ten $\mu \mathrm{g}$ of four types of organic tins were added to oil-based coloring vanish for wood-working (No. 7). For SIM, 8 ions were monitored $(\mathrm{m} / z 263$ and 261 for TBT, $m / z 318$ and 316 for TBT- $\mathrm{d}_{27}, m / z 366$ and 364 for TPT- $\mathrm{d}_{15}$ and $m / z 351$ and 349 for TPT; the underlined number is the $\mathrm{m} / z$ of the ion used for quantification).

6-4. 接着剂市販の接着剂 12 製品を分析し た. 水性接着剂のうち No. 1 から No. 4 までは, 水性塗料と同様に水に溶解し, 実験方法 4-4-1. に 記載の調製法を行って分析した。No. 5 から No. 11 までの 7 製品はアセトンに溶解し, 実験方法 4-4-2. の調製法を行い, No. 12 はジクロロメタン に溶解する実験方法 4-4-3. の調製法を行つて分析 した. その結果を Table 4 に示す.すべての製品か ら TPT は検出されなかつたが, TBT は, No.6, 10, 11 の 3 製品から検出された. No. 6 の接着剂に は $13.2 \mu \mathrm{g} / \mathrm{g}$ の TBT が含有されていた。この濃度 は, 公定法の検出限界值（TBT の無機スズ量とし て $1 \mu \mathrm{g} / \mathrm{g})$ を超過していた。法的には，公定法に より検出されれば違反となるので，この製品は違反

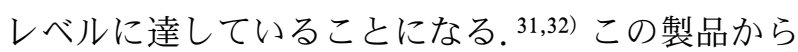
は高濃度の DBT が検出され，意図的に DBTを使
用（添加）しており，その不純物としての TBT が 検出されたものと考えられた。No.6から No. 8 は 同一メーカーの同一製品であるが，製造年月日が異 なっており, No. 7 と No. 8 からはTBT は検出さ れなかつた。また，No.9から No.11 は別の同一 メーカーの製品である. No. 11 は過去に高濃度の DBT 及び TBT 検出が報告された製品であるが, 19) 今回は，高濃度の TBT $(104.8 \mu \mathrm{g} / \mathrm{g})$ 及び DBT $(5153 \mu \mathrm{g} / \mathrm{g})$ とともにDOTも検出された。 No. 9 とNo.10からも高濃度のDOTが検出された。 DBT の代替として DOT が使用されていたと考え られる。濃度の差はあるものの，No. 6 から No. 11 までの 6 製品から DOT が検出された. 有機スズ の中でも，使用禁止になっていないDOT は，いろ いろな製品に使用されているようである.

水溶解接着剂 No. 4, アセトン溶解接着剂 No. 5 から No. 11 までの全 7 製品及び有機溶剂系接着剂 No. 12 に TBT, TPT 及び各サロゲート物質の 4 種 の標準品 $10 \mu \mathrm{g}, 100 \mu \mathrm{g}$ を添加し回収実験を行つ た. 水溶解接着剤 No. 4 は, TBT が 100-152\%, TPT が 25.1-29.0\%であったが，サロゲート補正を 行うと，いずれも良好な回収率（TBT が 95.8-97.0 \%, TPT が 99.0-100.1\%）が得られた. アセトン可 溶接着剤 No. 5 から No. 11 までの 7 製品でも, TBT が 62.0-111.3\%, TPT が 29.4-102.8\%の回収 率であったが，サロゲート補正を行い，やはり良好 な回収率（TBT が 97.3-102.4\%, TPT が 98.7103.8\%）が得られた。有機溶剂系接着剂 No. 12 で の回収率は, TBT が 150.0-152.7\%, TPT が 25.129.0\%であったが, サロゲート補正を行うと, TBT が 98.0-98.7\%, TPT が 86.6-90.1\%と，良好な回収 
Table 4. Analytical Results of Adhesive

\begin{tabular}{|c|c|c|c|c|c|}
\hline $\begin{array}{l}\text { Sample } \\
\text { No. }\end{array}$ & Usage & $\begin{array}{l}\text { TBT } \\
(\mu \mathrm{g} / \mathrm{g})\end{array}$ & $\begin{array}{l}\text { TPT } \\
(\mu \mathrm{g} / \mathrm{g})\end{array}$ & $\begin{array}{l}\text { Other organotin } \\
\text { compounds }\end{array}$ & Components \\
\hline 1 & $\begin{array}{l}\text { Water-based sticking glue } \\
\text { (water-soluble) }\end{array}$ & N.D. & N.D. & & PVP \\
\hline 2 & $\begin{array}{l}\text { Water-based glue } \\
\text { (water-soluble) }\end{array}$ & N.D. & N.D. & & \\
\hline 3 & $\begin{array}{l}\text { Water-based glue } \\
\text { (water-soluble) }\end{array}$ & N.D. & N.D. & & PVAL \\
\hline 4 & $\begin{array}{l}\text { Water-based adhesive } \\
\text { (water-soluble) }\end{array}$ & N.D. & N.D. & & Vinyl acetate resin $(55 \%)$, water $(45 \%)$ \\
\hline 5 & $\begin{array}{l}\text { Water-based adhesive } \\
\text { (acetone-soluble) }\end{array}$ & N.D. & N.D. & & $\begin{array}{l}\text { Cellulose }(20 \%) \text {, vinyl acetate resin }(5 \%) \text {, organic solvent } \\
(75 \%) \text {, acetone, ethanol, isopropanol, butyl acetate }\end{array}$ \\
\hline 6 & $\begin{array}{l}\text { Water-based adhesive } \\
\text { (acetone-soluble) }\end{array}$ & 13.2 & N.D. & $\begin{array}{l}\text { DBT } 2670 \mu \mathrm{g} / \mathrm{g} \text {, } \\
\text { DOT } 4.4 \mu \mathrm{g} / \mathrm{g}\end{array}$ & Silylated urethane resin $(100 \%)$ \\
\hline 7 & $\begin{array}{l}\text { Water-based adhesive } \\
\text { (acetone-soluble) }\end{array}$ & N.D. & N.D. & DOT $3.0 \mu \mathrm{g} / \mathrm{g}$ & Silylated urethane resin $(100 \%)$ \\
\hline 8 & $\begin{array}{l}\text { Water-based adhesive } \\
\text { (acetone-soluble) }\end{array}$ & N.D. & N.D. & $\begin{array}{l}\text { DBT } 0.3 \mu \mathrm{g} / \mathrm{g} \\
\text { DOT } 4.9 \mu \mathrm{g} / \mathrm{g}\end{array}$ & Silylated urethane resin $(100 \%)$ \\
\hline 9 & $\begin{array}{l}\text { Water-based adhesive } \\
\text { (acetone-soluble) }\end{array}$ & N.D. & N.D. & DOT $7700 \mu \mathrm{g} / \mathrm{g}$ & Acryl-denatured silicone resin (98\%) \\
\hline 10 & $\begin{array}{l}\text { Water-based adhesive } \\
\text { (acetone-soluble) }\end{array}$ & 0.1 & N.D. & DOT $590 \mu \mathrm{g} / \mathrm{g}$ & $\begin{array}{l}\text { Acryl-denatured silicone resin }(65 \%) \text {, synthetic resin }(30 \\
\%) \text {, inorganic compound }(5 \%)\end{array}$ \\
\hline 11 & $\begin{array}{l}\text { Water-based adhesive } \\
\text { (acetone-soluble) }\end{array}$ & 104.8 & N.D. & $\begin{array}{l}\text { DBT } 5150 \mu \mathrm{g} / \mathrm{g} \text {, } \\
\text { DOT } 22 \mu \mathrm{g} / \mathrm{g}\end{array}$ & $\begin{array}{l}\text { Special silicone-denatured polymer }(70 \%) \text {, inorganic com- } \\
\text { pound }(30 \%)\end{array}$ \\
\hline 12 & $\begin{array}{l}\text { Organic solvent adhesive } \\
\text { (dichloromethane-soluble) }\end{array}$ & N.D. & N.D. & & $\begin{array}{l}\text { Chloroprene rubber }(30 \%) \text {, organic solvent }(70 \%) \text {, cyclo- } \\
\text { hexane, } n \text {-hexane, isopropyl acetate, acetone }\end{array}$ \\
\hline
\end{tabular}

N.D.: not detected.

率が得られた。

6-5. 公定法との比較 前述したように, 接着

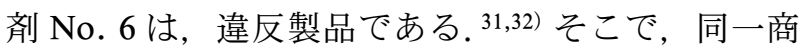
品名で，製造日の異なる 4 種の 8 製品について，今 回開発した GC/MS 法に加えて公定法も実施し, 両方法の比較検討を行つた. その結果を Table 5 に 示す. No. 13 と No. 14 が同一製造日の製品（同一 ロット）であり，以下，試料番号順に各 2 製品が同 一製造日の製品である.

GC/MS 法による TBT の定量值は, 各試料に内 部標準物質 $\mathrm{TBT}-\mathrm{d}_{27}$ を $10 \mu \mathrm{g} / \mathrm{g}$ 添加して, サロゲー 卜補正を行った值である。参考として, Table 5 に は TBT- $\mathrm{d}_{27}$ の回収率も記載した。 Table 5 に示すよ うに, No. 13 から No. 16 までの製品に規制基準值 以上の TBT が検出された。 さらに, やはり高濃度 の DBT が検出され，これら TBT は意図的に添加 した DBT の不純物が検出されたことが確認できた.

No. 17 から No. 20 の 4 製品からは TBT は検出さ れなかった。また，低濃度ではあるが，全製品から DOT が検出された. Figure 3 に試料 No. 14 の TIC を示す.
さらに，現公定法に従って，アルミナカラムなぞ による前処理法を行い, 二次元 TLC 展開後のジチ ゾン-TBT 錯体の発色による確認及びフレームレス AAS でのスズ量測定を行った. ${ }^{6)}$ No. 13 から No. 16 の 4 試料から TBT が検出され, No. 17 から No. 20 の 4 試料は検出されなかった. TBT が検出され た試料の場合でも, 発色直後に撮影した写真により 確認できたものの, 発色時間は数秒間であった。一 方，フレームレス AAS 測定によるスズ検出量は, TBT 含有量と比べると高濃度であった，TLC 法で は, DBT の発色も確認されており, フレームレス $\mathrm{AAS}$ 測定では, DBT 由来のスズも検出されたもの と考えられる.

今回開発した GC/MS 法と公定法の結果は, 法 的な違反製品として一致した. ${ }^{31,32)}$ 上記のように公 定法の場合, ジチゾン錯体の発色時間が非常に短 く, 錯体構造そのものが不安定である. また, 操作 も煩雑であり, 結果が出るまで数日間かかる. 一方, GC/MS 法は比較的操作が簡便であり, 繰り返し測 定も可能である. したがつて, 早急に公定分析法の 改定が必要と考えられる. 
Table 5. Comparison between GC/MS Method and Official Method

\begin{tabular}{ccccccc}
\hline \hline Sample No. & Lot No. & $\begin{array}{c}\text { TBT content } \\
(\mu \mathrm{g} / \mathrm{g})\end{array}$ & $\begin{array}{c}\text { TBT-d } \mathrm{d}_{27} \\
\text { recovery rate } \\
(\%)\end{array}$ & $\begin{array}{c}\text { DBT detection } \\
\text { amount } \\
(\mu \mathrm{g} / \mathrm{g})\end{array}$ & $\begin{array}{c}\text { DOT detection } \\
\text { amount } \\
(\mu \mathrm{g} / \mathrm{g})\end{array}$ & $\begin{array}{c}\text { TBT detection } \\
\text { by official method }\end{array}$ \\
\hline 13 & 080405 & 10.8 & 50.2 & 1650 & 2.6 & Detected \\
14 & 080405 & 10.8 & 87.6 & 2130 & 4.4 & Detected \\
15 & 080408 & 10.8 & 87.4 & 2370 & 3.4 & Detected \\
16 & 080408 & 10.2 & 87.3 & 2260 & 4.1 & Detected \\
17 & 090106 & N.D. & 81.9 & N.D. & 4.0 & N.D. \\
18 & 090106 & N.D. & 82.7 & N.D. & 3.5 & N.D. \\
19 & 090525 & N.D. & 77.7 & 0.70 & 3.8 & N.D. \\
20 & 090525 & N.D. & 70.8 & N.D. & & N.D. \\
\hline
\end{tabular}

N.D.: not detected.

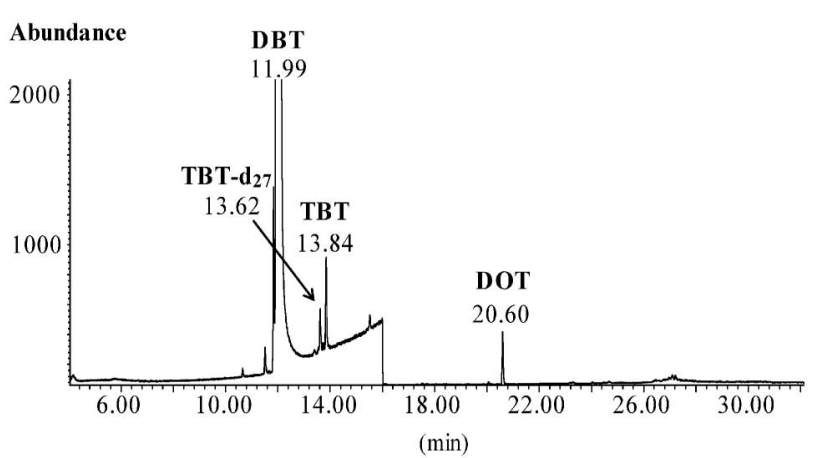

Fig. 3. Total Ion Chromatogram (SIM Mode) of a Recalled Adhesive Product (No. 14)

\section{ま と め}

「有害物質を含有する家庭用品の規制に関する法 律」で使用が禁止されているトリブチルスズ化合物 （TBT）及びトリフェニルスズ化合物（TPT）の公 定分析法の改定法を検討した。まず，TBT 及び TPT を誘導体化（エチル化法と水素化法）し，GC/ MS で検出する方法を検討した。 TPT では，エチ ル誘導体の方がより高感度に検出できた．前処理法 は，1）繊維製品，2）水性製品(水性塗料など)，3） 油性製品（油性塗料，靴墨，ワックスなど），4）接 着剂（アセトン可溶性，水・油ともに難溶性）と, 分析対象品によって異なる方法を検討した．市販製 品の分析は，水素化法でスクリーニングを行い，エ チル化法で定量を行った。各製品への添加回収実験 を行い, TBT と TPT の標準品のみの添加では, 良 好な回收率が得られない製品もあった。しかし，内 部標準物質として各サロゲート物質（TBT- $\mathrm{d}_{27}$, TPT- $\mathrm{d}_{15}$ ）を用いると，良好な回収率（TBT が 94.5
-118.6\%, TPT が 86.6-110.1\%）が得られた。開発 した分析法で，市販 31 製品中の TBT, TPT を分析 したところ，1 製品（接着剂）から，法規制基準值 （スズとして $1 \mu \mathrm{g} / \mathrm{g}$ ）を超過する $13.2 \mu \mathrm{g} / \mathrm{g}$ の TBT が検出された。そこで，製造日の異なる同一製品を 分析したところ， 8 製品中 4 製品から規制基準超過 の TBT (10.2-10.8 $\mu \mathrm{g} / \mathrm{g})$ が検出されるとともに, $1000 \mu \mathrm{g} / \mathrm{g}$ 以上の高濃度 DBT が検出された. 当該 製品には，DBT の不純物である TBT が残存してい たものと考えられた.

本法は，現公定法の改定法として十分適用できる ものと考えられる，特に，従来困難であった油性製 品やゴム系接着剤中の TBT, TPT の分析，並びに DBT 含有試料中の残存 TBT の分析などには，有効 な分析法と考えられる.

謝辞 現公定法の実施にあたり，御協力頂いた 大阪府立公衆衛生研究所の吉田俊明主任研究員, 吉 田仁研究員並びに田中栄次主任研究員に深謝いたし ます。御助言等を頂きました国立医薬品食品衛生研 究所の鹿庭正昭博士, 北九州市立大学の岩村幸美博 士, 大阪市立環境科学研究所の大嶋智子副主幹, ま た，過去に TBT を検出した接着剤（No. 11）を御 提供頂きました北九州市環境科学研究所の苗床江理 研究員に感謝いたします。

\section{REFERENCES}

1) Evans C. J., Karpel S., "Organotin Compounds in Modern Technology," Elsevier Science Publishers, Amsterdam, 1985.

2) Arakawa Y., Muroga K., Koishi H., Morita 
A., Iwasaki T., Nakashima H., Hori S., Trace Nutrients Res., 8, 1-8 (1991).

3) Arakawa Y., Kuriyama T., Kunitomo Y., Morita A., Iwasaki T., Nakashima H., Hori S., Biomed. Res. Trace Elements, 3, 319-329 (1992).

4) Arakawa Y., Hirano Y., Murata J., Nakashima H., Takeuchi T., Nakano Y., Biomed. Res. Trace Elements, 12, 107-112 (1995).

5) Arakawa Y., Biomed. Res. Trace Elements, 11, 259-286 (2000).

6) Ministry of Health, Labour and Welfare, Act on Control of Household Products Containing Harmful Substances. Act No. 112, 1973.

7) Kojima S., Nakamura A., Kaniwa M., Jpn. J. Toxicol. Environ. Health, 25, 141-146 (1979).

8) Kojima S., Analyst, 104, 660-667 (1979).

9) Nakashima H., Matunaga I., Tani N., Proceedings of Osaka Prefectural Institute of Public Health. Ed. of Industrial Health, 19, 45 -49 (1981).

10) Nozaki Y., Hirata Y., Maeda T., Annual Report of the Miyazaki Prefectural Institute of Public Health and Environment, 5, 58-61 (1993).

11) Yamanobe H., Kishimoto K., Iwasaki Y., Kan T., Nakamura H., Ann. Rep. Tokyo Metr. Res. Lab. P.H., 46, 815 (1995).

12) Nakashima H., Hori S., Iwagami S., Nakazawa H., Fujita M., Bunseki Kagaku, 36, 867-871 (1987).

13) Nakashima H., Hori S., Nakazawa H., Jpn. J. Toxicol. Environ. Health, 36, 15-20 (1990).

14) Nakashima H., Matsunaga I., Miyano N., Proceedings of Osaka Prefectural Institute of Public Health. Ed. of Industrial Health, 21, 41-46 (1983).

15) Nakashima H., Matsunaga I., Proceedings of Osaka Prefectural Institute of Public Health. Ed. of Industrial Health, 22, 47-53 (1984).

16) Yagi M., Ichihashi A., Annual Report of Amagasaki City Institute of Public Health, 17, 35-40 (1990).

17) Yamada S., Ozone K., Ueno S., Ishizaki M., Annual Report of Ibaraki Prefectural Institute of Public Health, 31, 38-41 (1993).

18) Hasegawa K., Utsunomiya A., Setsuta S.,
Bull. Kanagawa P. H. Lab., 24, 38-42 (1994).

19) Naedoko E., Yamaguchi R., Higuchi M., Yamato Y., Takahashi M., Abstracts of papers, the 41th Annual Meeting of Zenkoku Eisei Kagaku Gijutsu Kyogikai, Yamanashi, 2004, pp. 206-207.

20) Ooshima T., Miyamoto T., Mori Y., Abstracts of papers, the 44th Annual Meeting of Zenkoku Eisei Kagaku Gijutsu Kyogikai, Mie, 2007, pp. 291-292.

21) Ohno H., Suzuki M., Iwama M., Nakashima S., Aoyama T., Yamamoto K., Ann. Rep. Nagoya City Public Health Res. Inst., 42, 1720 (1996).

22) Kawamura Y., Maehara T., Suzuki T., Yamada T., J. Food Hyg. Soc. Japan, 41, 246-253 (2000).

23) Ohno H., Suzuki M., Nakayama S., Aoyama T., Mitani K., J. Food Hyg. Soc. Japan, 43, 208-214 (2002).

24) Ohno H., Suzuki M., Aoyama T., Mitani K., Ann. Rep. Nagoya City Public Health Res. Inst., 49, 19-22 (2003).

25) Ohno H., Suzuki M., Aoyama T., Mitani K., J. Food Hyg. Soc. Japan, 44, 208-212 (2003).

26) Hattori Y., Kobayashi A., Takemoto S., Takami K., Kuge Y., Sugimae A., Nakamoto M., J. Chromatogr., 315, 341-349 (1984).

27) Nakamuta K., Kinoshita M., Matsubara H., Annual Report of the Fukuoka Institute of Health and Environmental Sciences, 24, 135138 (1999).

28) Iwamura T., Kadokami K., Jin-ya D., Hanada Y., Suzuki M., Bunseki Kagaku, 48, 555561 (1999).

29) Iwamura T., Kadokami K., Jin-ya D., Tanada K., Bunseki Kagaku, 49, 523-528, (2000).

30) Kawakami T., Isama K., Nakashima H., Ooshima T., Tsuchiya T., Matsuoka A., Yakugaku Zasshi, 130, 223-235 (2010) .

31) Osaka Prefectural Government: 〈http:// www.pref.osaka.jp / hodo / index.php?site = fumin\&pageId $=1134\rangle$, cited 19 April, 2010.

32) Konishi Co., Ltd.:〈http://www.bond.co.jp/ news/news_20090721/index.html $\rangle$, cited 19 April, 2010. 